\title{
Devaluating The Nandas -A Big Loss To The History Of India
}

\author{
SANJAY CHAUDHARI \\ Department Of History, Culture And Archaeology, Dr. Ram Manohar Lohia Avadh University, Faizabad, Uttar \\ Pradesh, India
}

\begin{abstract}
Indian historians could be blamed for having hostile attitude towards the Nandas. Though Nandas established the first ever empire, covering almost area of present India, they were never recognized for the same. Almost Indian historians neglected their acheivements and have tried to reduce the span of their rule. The Nandas have been referred by distant people of ancient Iran and the classical writers of the Greece. Their strength has been narrated by the scholars who accompanied Alexander in India. Interesting to state that no evidences are available which could confirm the war, that took place between the last Nanda and Chandragupta. Even though the historians narrated the event stating it as a revolution by the people which ousted the last Nanda king. There are few Sanskrit chronicles which connected Chandragupta to Nanda King. These chronicles have stated that Chandragupta was the legitimate son of the last Nanda king. But Indian historians tried their best to present Buddhist evidences which state Chandragupta a resident of Pippalvana and related to Nandas any way. To devaluate the Nandas has created a big historical loss to our ancient history. The whole period from Indus valley civilization to the establishment of sixteen Mahajanapadas is still in the dark. Some questions has been raised in the thesis presented below.
\end{abstract}

Keywords-The Brahmanas, The Varna System, The Puranas, Classical writers, Xenophon, Historiography during British India, Chandragupta.

\section{INTRODUCTION}

The British government took over the task of civil administration in India from 1857 A.D. To send young English administrators to India, a proper introduction of the people of India and their customs, was felt a necessity. They started to translate all of the Indian literature that could be helpful to young aspirants, expected to run the civil administration in India. Some of Indians also started to write and compile Indian history. Most of them were engaged by British historians who needed their help to understand the Sanskrit terminology. The problem was created from that moment only. The Indian historians were aimed to establish that it were Dharmasastras and the Smritis that dominated the masses before Muslims. There were vested interests of Britishers which precipitated in the theories like Aryan theory and Mills division of Indian history in to Hindu, Muslim and British India. The historians did not pay proper attention to the region falling before $6^{\text {th }}$ century BCE. To accomplish their task, they even reduced the ruling period of the Nandas.

\section{DEVALUATING THE NANDAS - A BIG LOSS TO THE HISTORY OF INDIA}

The Indian historians asserted that Indians lacked the sense of history. If it is so, then it has number of causes. They did not felt it important to keep the record. They did not want keep those historic records as they had little to their concern. It could not be maintained as there are various writers in the medieval period, who wrote, and had sense of history. But that period belonged to the Muslim rulers and that has no utility to them. We just could not state that the writers of the ancient India, do not had the sense of history. Puranas have mentioned about history. But Puranas himself seem to have been busy to establish things with their vested interests. Puaranas could not be trusted as they are not impartial. Even Buddhist literature is also not impartial, especially the literature written in Sanskrit. Much before, from 1857A.D., company officials and British government has started to think about taking over the civil administration of Indian colony. ${ }^{1}$ India was to be governed under the principles of the British governance. An administrative structure was to be framed, and was to be run by the trained and capable administrators. Most of them had to be sent from England. They were quite ignorant of the Indian conditions. They required proper training and knowledge. There was no written history of India available to study and learn about India. British government started to translate the rule books and sources of the Indian society. British government was aware of the fact that they had snatched the land from Muslims. Muslims were not ready to support them in administering India. There were Muslim laws prevalent all over India. The language was also Persian. Opposition of Muslims would have been a matter of their concern. The English have to search a major group that could be helpful to rule in India. The group should have numerical strength which could counter Muslims. They were hopeful; this will balance the expected non-cooperation of 
the Muslim majority. The English looked towards caste Hindus and started to encourage them. The caste Hindus also reacted accordingly. The Aryan theory was introduced in 1859 A.D., which started according to their wish. Caste Hindus were less in number but had enough potential to be used against Muslim influence. English started to create an atmosphere which stated that people having faith in Dharmasastras and Smritis are outnumbered Muslims. They started to encourage Brahmin customs and laws. Muslim laws and language was discouraged. Indian historians started to write Indian History which was aimed to establish that Brahmin ideology was the ancient old, eminent ideology prevalent over Indian subcontinent, before Muslim invasion. The history compiled such a way is our recognized history of today. Though, some of us call it a tentative history which required a lot of corrections.

Historians believe that political instability has been a salient feature of Indian subcontinent. It was established to support the alien rule of Englishmen on India. English historians have written that India was always ruled by the foreigners. It was justification for the foreign rule of British in India. Historians established that India lacked evidences that could prove that there was any governance between period of Indus and the era of sixteen Mahajanapadas. I believe those evidences will never be found again as they were discarded. It is interesting to find that if Buddhist text presents a list of Mahajanapadas then simultaneously Jaina texts also present another list. Mahabharata also presents a different list. Mahajanapadas existed at the eve of the birth of Lord Buddha, hence it becomes Buddha age. Some the kings like Pradyota and Bimbisar are said to have been contemporary of Lord Buddha. Their ruling period has been established on the basis of that evidence only. Lord Buddha's date is still controversial and is yet to be finalized. It may go as far as 1000 B.C. If it happened, date of Nandas will certainly go before. The first Nanda king is said to have established a vast empire extended from Bengal to almost whole of the Gangetic valley and upto Godavari in east. It can be stated that it was the first all Indian empire ever existed historically. The first Nanda has been mentioned in Cyropaedia, hence he can be placed in the sixth century B.C. But historians believe that the empire of Chandragupta was the first all Indian empire. Chandragupta's empire included modern Pakistan and even the parts of Afghanistan. Pakistan and Afghanistan are sovereigns and can't be called India. But the empire established by Nandas, included maximum of the present India, geographically. None of the historians dare to break this tradition. Chandragupta added western parts to it. The north-western part of the subcontinent was overrun and was united politically, by Alexander. But historians went on asserting that the first all Indian empire was established by Chandragupta. It wasn't easy task for Chandragupta. It was Kautilya, a staunch Brahmin, made it possible for Chandragupta. Kautilya, said to have not only trained him but also made all strategy to defeat Nanda king. And as the Brahmins were the only intellectuals always selfless and dedicated for the cause of others. He appointed Chandragupta as the King of Magadh. There were no Brahmin ministers attached to Nanda kings and hence they started to call Chandragupta as the first all India emperor, instead of Nandas.

There are also defamations about the origin of the Nandas. They started to highlight the issues related with the origin of the Nandas. Nandas have been stated of low origin in the most of the known texts. Puranas have stated that he was born of a Shudra woman ${ }^{2}$. It is believed that the father of the first Nanda may have been a Kshatriya. ${ }^{3}$ Parishishthparvan has stated that the first Nanda was born of a courtesan. ${ }^{4}$ The classical writers wrote whatsoever was told to them by the people of western India. ${ }^{5}$ The objective of the historians was to prove that the Brahmin traditions was prevalent in the concerned period. They were trying to establish that the Varnashrama Dharma was so deeply rooted in the time of Nandas, in the contemporary society. According to Varna system, only Kshatriyas has legitimacy to rule. But Nandas, lacked that legitimacy, hence, were not tolerated by the people. The evidences were presented through foreign writers, hence were justified by them. The people's hatred also presented the acceptance level of the Brahmanic traditions and customs. People were sticked to Varna rules and were not ready to accept the rule of any non-Kshatriya over them. So Nandas were rejected by the people because of their low origin. People rejected the rule of Nandas because he was born of a prostitute woman. All this goes according the provisions made in the Dharmasatras.

Dharmasastras and Smritis have also prescribed the qualities and the character of the person to become a king. Nanda kings also did not fit to those qualities. Nandas have been wealthy kings. Their enormous wealth has been referred to by Ceylonese, Chinese and Xenophon ${ }^{6}$. But it was so because they were ruling over a vast territory. None Indian king has ruled over a territory larger than them. His territory was highly fertile and prospering. His resources were large and revenue was enormous. Why should one object about his wealth. Kathasaritsagar states that the last Nanda had 99 crores of gold pieces. ${ }^{7}$ Mamulnar has also referred to enormous wealth of the Nanda king. ${ }^{8}$ Nanda king has been blamed of being greedy. ${ }^{9}$ Traditions place greediness as a bad quality of personality. A king should not be greedy. It was a drawback and due to which, Nanda was not suitable for kingship. Having moral qualities and character is essential condition for a king. Dharmasutras and Smritis recommend a good character for the king. Nandas did not fulfill the requirements presented in the Brahmin texts hence he was disliked by the people. Nanda kings were ruling over a vast territory. To administer a vast territory, a huge bureaucracy was needed. His huge and outstanding army has been mentioned by the various sources. Feudalism has never been the part of Indian political traditions. Feudalism evolved after some time 
later when several immigrant families started to rule in Indian subcontinent. Mauryan kings also administered with the help of huge bureaucracy. Though, Kautilya hints about feudal setup in his chapter 'Janpadnivesh' of Arthasastra. This bureaucracy was paid. His huge standing army was also paid. It was kings' responsibility to arrange required revenue to pay them. Hence, any delay or irresponsibility in paying tributes was harshly handled. Kautilya himself has kept 'Rajkosha' on top priority. Revenue collection was on the top priority of the state. The developmental works of the Nanda king has been referred in Hathigumpha edict. Nanda kings are said to have got developed irrigation system called 'Nandopakramani Manani' ${ }^{10}$. Nanda kings were progressive kings. None of the progressive king may be labeled as greedy. Same conviction was made for Mauryan kings also. We should not forget the necessities of a extensive empire. Both have been the faulty explanations made by the learned historians.

Nanda king was defamed by another conviction. It is stated that the first Nanda has illegal affair with the queen. It is stated that last Shishunaga kings' wife has criminal affection towards the first Nanda. The first Nanda took advantage of it. He killed the king and usurped the legitimate right of the princes. It is stated that the first Nanda acted as patron to the minor princes for some time. The evidence of Ramgupta is very famous. Chandragupta-II has killed his own brother Ramgupta. He married to his wife Devi. Historians justified that by stating that Ramgupta was incapable ruler and Chandragupta-II did it to save the Gupta empire. But they did not explain about, how his marriage with Devi, was justified. The incident has been reported in texts from seventh century to eleventh century. The incident has been deplored by every text. Even edicts of ninth century and tenth century have mentioned about the incidence, declaring that Kalyuga has arrived. Historians always presented all of the achievements made by Chandragupta-II. No one started to ignore him. Nanda king established an empire, even larger and extensive than Gupta, but suffered in the hands of historians. A person capable of establishing such a large empire could not be ignored for such evidences which are entirely secret and intimate.

Puranas state that the first Nanda king has exterminated almost all Kshatriya kings from the earth. He was called 'Sarvakshatrantaka' and 'Ekrat'. He is stated to have defeated almost all of the Kshatriya clans of the Puranas. The list included the Ikshwaku, the Panchal, Kashi, the Hehayas, Kalinga, Asmaka, the Kurus, Mithila, the Saursenas and the Vitihotras. It also indicates that all of the Puranic kshatriya clans has come to a end and new Kshatriyas has to be evolved. It is an indication of the renewal of the ruling class. When Nanda king established political unity in the subcontinent for the first time, he should have to be admired. He should not be criticized for unfair method to ascend the throne of mighty Magadha empire. The first Nanda, not only destroyed these old ruling clans but also provided political stability. He should have to be seen in his ability and strength. Magadha has little alternatives left after the death of last Shishunaga king, Kalasoka-Kakvarna. The first Nanda came forward to play his due role. He succeeded. His dedication and achievements still need the due appreciation from the historians.

Ayodhya was the centre of the Brahmin ideology. But the influence of Brahmin ideology was negligible. Ayodhya was an important cantonment of the Nanda kings ${ }^{11}$. Nanda kings did not recognized the Brahmin ideology and traditions. He never showed the expected respect or support to the ideology. Some sayings support it. A saying connected with Brahmin named Chanakya proves it. The story also presents the desire of the narrator to depose the Nandas. Brahmin ideology required the support of the ruler for extension. Nandas did not extend any support. Brahmin thought that it were the Nandas who were big obstacle in their progress in the Gangetic valley. It is said that people were fade up with the rule of the Nandas. Sources also state that the people of the Gangetic valley felt proud to be resident of the region ${ }^{12}$. The two statements are contradictory and are important in this regard. It raises questions which may have some very bitter answers.

Puranas state that total ruling period of the first Nanda was 88 years. Historians are in no mood to accept this. They justify their denial but what about the Puranic evidence. Another Purana states that the first Nanda ruled for about 28 years alone ${ }^{13}$. He was followed by his eight successors Panduka, Pandugatika, Bhutpal, Rashtrapal, Govinashaka, Dashashiddhaka, Kaivarta and Dhanananda. When Purana state that all these successors rule for 16 years, historians accept it. It is interesting that the historians are in no mood to allow the Nandas a larger ruling period. They accept one statement but reject the consecutive one. They believe that after the first Nanda, they started to disintegrate. The Nanda dynasty was heading towards the end. Hence they are satisfied to allot an average one and a half year to each successor of the first Nanda. But what were the signs that show that the dynasty was heading towards the end. The last ruler of the Nanda dynasty was Dhanananda. Who is said to have ousted by a Brahmin Kautilya, with the help of his student, Chandragupta. The army of the last Nanda has been described by Curtius as consist of 200000 infantry, 20000 cavalry, 2000 charioteers and 3000 elephants. Indian historians felt pride to state that such a huge army of the last Nanda created fear among the soldiers of Alexander, the great. They refused to cross over the Vyas. Then how it can be proved that dynasty was breathing his last.

It could have been a family struggle which resulted in dispossession of the last Nanda king. Some of the Sanskrit texts hinted it. These included some Sanskrit chronicles ${ }^{14}$, which state that Chandragupta was the son and legitimate hire of the throne. Mudrarkshasa also depicted a struggle in the family. None of the historical 
source present the fact that a direct war took place between the two warriors. Milindpanh mentioned about the battle. It states about a Holocaust ${ }^{15}$. Such a devastating and bloody war needs to be mentioned if any one mentions about the conflict. But none reported it. Kautilya has been mentioned everywhere, who was more indulged in intrigues rather to wage a direct war. The end of the last Nanda did not signaled about any big change nor gives any glimpse of people's revolution. It was simply transfer of power. It was family struggle, out of which the group of Chandragupta succeeded. The involvement of Kautilya is not clear. Whether he was really in the scene or is merely a fictitious cast, casted by the writers of the concerned texts. We don't find any influence of Kautilya, after Chandragupta's accession. And if, he happened to be the prime minister of Chandragupta, Megasthanese did not found him important enough, to be mentioned in his Indika.

\section{CONCLUSION}

There can be a number of reasons, historians devaluated the Nandas. They, in order to keep the era without Brahmin influence short, tried to shorten the ruling period of Nandas. There was an era of Chandragupta was available just after Nanda, which could be attached to Brahmin importance. There was plenty of literature available mentioning a Brahmin, Kautilya and a Chandragupta, the king of Magadha. It was desirable to highligh them in order to draw the requisite results. It was due to the strong desire to present Brahmin influence in Indian politics, as early as possible. Nandas were undesired kings, whose era lacked any Brahmin influential figure. Hence they had to be defamed and their period has to be cut short. The evidences were collected, presented and Kautilya, Chandragupta and Magadha were linked together. Kautilya has been portrayed as the trainer and teacher of Chandragupta. Rest of the evidences which could create any problem has been left to get destroyed itself. It is astonishing that even after that, Chandragupta did not follow the Brahmanism. He is said to have followed Jainism. Even Bindusar and Asoka did not follow the Brahmin ideology. Bindusar seems to have patronized almost all of the ideologies prevalent then. The rulers of the peace period are often seen involved in such activities.

In order to create a platform to show that new circumstances aroused because a people's revolution has took place, those texts, which stated that Chandragupta belonged to the royal family of Nandas, has been denied and all those texts which suited were accepted. Buddhist sources were accepted which say that Chandragupta belonged to a warring tribe of Pippalavana. It was tried to establish that without Kautilya, Chandragupta was nothing. The devaluation of Nandas resulted in loss of some incredible evidence which could have been vital to establish and recreate the history of the period before the Mahjanapadas. It is, undoubtedly, a big loss to Indian history inflicted by its own historians.

\section{REFERENCES AND COMMENTS}

[1] The Regulating act of 1773 A.D., passed for India by the Parliament of Britain starts as 'for the better management of the affairs of East India Company, as well in India as in England.' It unveils the objectives of the Englismen in India. Imperial Gazetteer of India, Volume-IV, 1908, p:14. Moreover the famous Queens' declaration of 1858 A.D. also supports the objective of good governance, as all Indians had to be considered as Her subjects.

[2] 'Shudragarbhodavah'. Goyal S.R., Maurya Samrajya, Jodhpur, 1993, p: 219.

[3] His father has been termed as 'Kshatrabandhu'. Historians have put the meaning as Kshatriya. Kshatra has been accompanied with 'Bandhu', which means the cooperator or supporter. Hence the word 'Kshatrabandhu' may have the meaning 'the supporter of Kshatriya or Kshatra'.

[4] 'Ganikakusijanma'- Parishishtaparvana, 46, Vol.:06, 131-132.

[5] McCrindle, Invasion of India, p:222.

[6] Cyropaedia, Translated by Walter Miller, Volume-III, p225.

[7] Kathasaritsagar, Translated by Turner, p:21.

[8] Ayangar, The beginning of South Indian History, p:89.

[9] Mahavansha, Translated by Turner, p:39.

[10] Ashthadhyayi, Translated by S.C.Basu, 2.4.21.

[11] Kathasaritsagar, Translated by Turner, p:21.

[12] McCrindle, Megasthanese and Arrian, 1926, p:141.

[13] Roychowdhury H.C., Political History of Ancient India, Calcutta, 1973, p:208; Goyal S.R., Maurya Samrajya, Jodhpur, 1993, p:229.

[14] S.B.E., Volume-xxxvi, p:147-148. 